\title{
Deep-Fat Frying of Potatoes in Palm Oil in Relation to Quality Characteristics Assessment
}

\author{
Hassan , I.M. \& Abou-Arab, A.A. \\ Food Science Dept., Fac. of Agric. Ain-Shams Univ., Cairo, Egypt.
}

\begin{abstract}
Sensory and chemical attributes of palm oil used for repeated and discontinuous deep-fat frying of potato chips at elevated temperatures were followed. Polyunsaturated fatty acids (PUFAs) decreased in direct proportion to frying times, whereas saturated FAs were found to inversely increase. A strong degree of correlation $\left(\mathrm{R}^{2}\right)$ was found between $\mathrm{C}_{18: 2} / \mathrm{C}_{16: 0}$ ratio and the frying time. Free fatty acids were released and their concentration in the palm oil often increased with repeated use. From acid values and polar compounds contents of the used palm oil, it was obvious that thermoxidative alterations took place mainly instead of the hydrolytic process. Frying palm oil was also analyzed for ultraviolet absorption $\left(\mathrm{A}_{232}\right.$ and $\mathrm{A}_{268}$ ), peroxide value (PV) and thiobarbituric acid (TBA) value during repeated and discontinuous deep-fat frying. The correlation coefficients ( $r$ ) between heating times and $A_{232}, A_{268}, P V$ and TBA values were $0.82,0.45,0.42$ and 0.95 , respectively . During frying stages, both $\mathrm{A}_{400}$ and $\mathrm{A}_{450}$ of the used palm oil were measured. Frying times were highly correlated with the steady and proportional increment in $\mathrm{A}_{400}$ and $\mathrm{A}_{450}$. Sensory analysis of the palm oil used in potatoes frying exhibited that quality deterioration has taken place with the progression of frying times. During frying process, there was an inverse relationship between odour and colour sensory scores and frying times with a correlation coefficients of $r=$ -0.9204 and -0.9667 , respectively. Various prediction models for assessing accurately frying times using different dependant variables were established.
\end{abstract}

Key words: quality characteristics, deep-fat frying, palm oil, potato chips.

\section{INTRODUCTION}

Frying is one of the most popular procedures of food preparation worldwide. Hence the use and abuse of frying oils has become of great concern for health administrations and for consumers. If these oils are subjected to extensive heat abuse, their nutritional value not only be impaired but also pose hazards to health (Blumenthal, 1996).

Deep fried foods especially Falafel, potatoes and eggplant are a group of major items of the Egyptian diet. During deep frying, the oil is exposed continuously or repeatedly to elevated temperatures in the presence of air and moisture. A number of chemical reactions including oxidation and hydrolysis occur during this time, as do changes during thermal decomposition. As these reactions proceed, the functional, sensory and nutritional quality of the oil deteriorates and may reach a point where it is no longer possible to prepare high quality fried products and the frying oil will have to be discarded (Stevenson et al., 1984). The rate of formation of decomposition products, and indeed the products themselves vary with food being fried. In addition, it has also been shown that repeated and intermittent heating, as in restaurants and household frying, increases the degradation of lipids, probably owing to peroxide formation and decomposition during reheating, cooking and cooling cycles.

There are numerous analytical methods for assessment of frying oil deterioration, but no single technique can easily evaluate frying oil quality. The method(s) chosen will depend on the accuracy of measurement, the ease of carrying out, the cost of analysis and the time needed to carry on the evaluation. Therefore, it is very important to have simple, rapid, decisive and objective methods for assessing accurately frying oil quality.

Changes occurring in frying oils can be followed by a large variety of analytical methods such as free fatty acids (FFA), or acid value, thiobarbituric acid (TBA) tests and peroxide value (PV) as well as UV absorption, ratio of absorbance $\left(\mathrm{A}_{400} / \mathrm{A}_{450}\right)$, determination of polar compounds and dielectric constant. Sensory tests including odour, flavour and colour and physical properties including foam height and viscosity are also 
of great importance in assessing frying oil quality. The reliability of these tests depends mainly on the type of frying oil and the food being fried as well as the experience and facilities available in an institution of concern (Berger, 2005).

The present work is a part of a project entitled "Rationalizing Utilization of Edible Oils in Local Consumption", financed by the Academy of Scientific Research and Technology collaborated with Food Sci. Dept., Fac. Agric., Ain Shams Univ. Cairo, Egypt, for monitoring and specifying the quality of most common frying oils in Egypt during and after frying operations. Therefore, the objective of this study was to quantify the influence of repeated and discontinuous fryings on both quality characteristics and stabilities of the frying oil. The relationship between the investigated quality parameters and the number of fryings as well as heating times were also established.

\section{MATERIALS AND METHODS}

Palm oil (PO) was purchased from a local oil processing factory. The PO samples were taken from the oil storage tanks before being bottled. The oil was stored below $15^{\circ} \mathrm{C}$ in the dark and used within 15 days as purchased. Potatoes were purchased from a local store. Analysis of the raw potatoes showed the following components: moisture $77.48 \pm 0.87 \%$ whereas protein, fat, ash and total carbohydrates were $2.42 \pm 0.23 \%, 0.28 \pm 0.09 \%, 1.13 \pm$ $0.06 \%$ and $17.82 \pm 1.12 \%$ (on fresh matter), respectively.

The peeled potatoes were chopped into round slices ca. $1.0 \pm 0.15 \mathrm{~mm}$ thickness and $6.0 \pm 0.20 \mathrm{~cm}$ diameter and submerged in water until needed. Frying was performed in four $3 \mathrm{~L}$ commercial electrical fryers (Phillips) where the surface to volume ratio was 0.21 , equipped with a thermostat to regulate temperature.

The frying protocol for the oil included intermittent frying of potatoes at $180^{\circ} \mathrm{C}$. The proportion of potato slices to frying oil in the repeated frying was always kept at $500 \mathrm{~g} / 3 \mathrm{~L}$ $(1: 6 \mathrm{w} / \mathrm{v})$ eliminating one frying after five frying and emptying its contents to make up the volume of other fryers to $3 \mathrm{~L}$. This was done to avoid using fresh oil to replenish the oil removed along with the fried potatoes. Time required to reach and keep the bath oil at $180^{\circ} \mathrm{C}$, before introduction of potatoes, was
11 min. Temperature started at $180^{\circ} \mathrm{C}$ and ranged from $122^{\circ} \mathrm{C}$ to about $160^{\circ} \mathrm{C}$ during frying operations. Potato slices were then fried for $7 \mathrm{~min}$. After the end of each frying, the oil was cooled to $120^{\circ} \mathrm{C}$ within about 25 min, and then the oil was heated again to $180^{\circ} \mathrm{C}$ to begin with a new frying cycle. Twenty batches of potatoes were fried within 4 days at a rate of five fryings per day. A total heating and frying times per day was 210 min. A total heating and frying time during 4 days was $14 \mathrm{hr}$. Fig. (1) shows the changes in palm oil temperature during the heating and frying operations each day (5 fryings).

Analytical methods: Fatty acid methyl esters were prepared by boron-triflouridemethanol according to Metcalf et al. (1966). Fatty acid methyl esters of control and used frying oils were identified in duplicate using Perkin-Elmer Gas Liquid Chromatography series 8300 equipped with a $2 \mathrm{~m}$ column (packed with 15\% Ov-275 chromosorb W, $\mathrm{A} / \mathrm{W}, 80 / 100)$ and flame ionization detector (FID). Column temperature was $100^{\circ} \mathrm{C}$ for 2 min and increased to $190^{\circ} \mathrm{C}$ with rate of $7^{\circ} \mathrm{C} / \mathrm{min}$, then isothermally for $20 \mathrm{~min}$ at $190^{\circ} \mathrm{C}$ (Ashour, 1991). Identification of the fatty acids on the chromatogram was made by comparing the retention times of the frying oil methyl esters with those of known mixtures of methyl esters run on the same column under the same conditions. The fatty acid composition was expressed as area percentage of the total area from all methyl esters. Three samples of control and used oil from the fifth, tenth, fifteenth and twentieth fryings were analyzed in triplicate for the following parameters: Acid values (AVs) expressed as \% oleic acid, Peroxide value (PV), and polar compounds (PC) were determined according to AOAC (1995). Thiobarbituric acid value (TBA) was determined as $\mathrm{mg}$ malonaldehyde per $\mathrm{kg}$ oil according to Keeney (1971). Light absorption of the oil at both 400 and $450 \mathrm{~nm}$ was measured spectrophotometrically using Unicam HE $\lambda$-IOS $\alpha$ UV-visible Spectrophotometer (model v2.03) according to Hassan (1980). Natural conjugated and unconjugated constituents were determined using UV absorption at 232 and 268 $\mathrm{nm}$ in purified solvent as described by Danopolus \& Ninni (1972).

Sensory evaluation: The odour intensity and the colour of frying oil were evaluated by a 


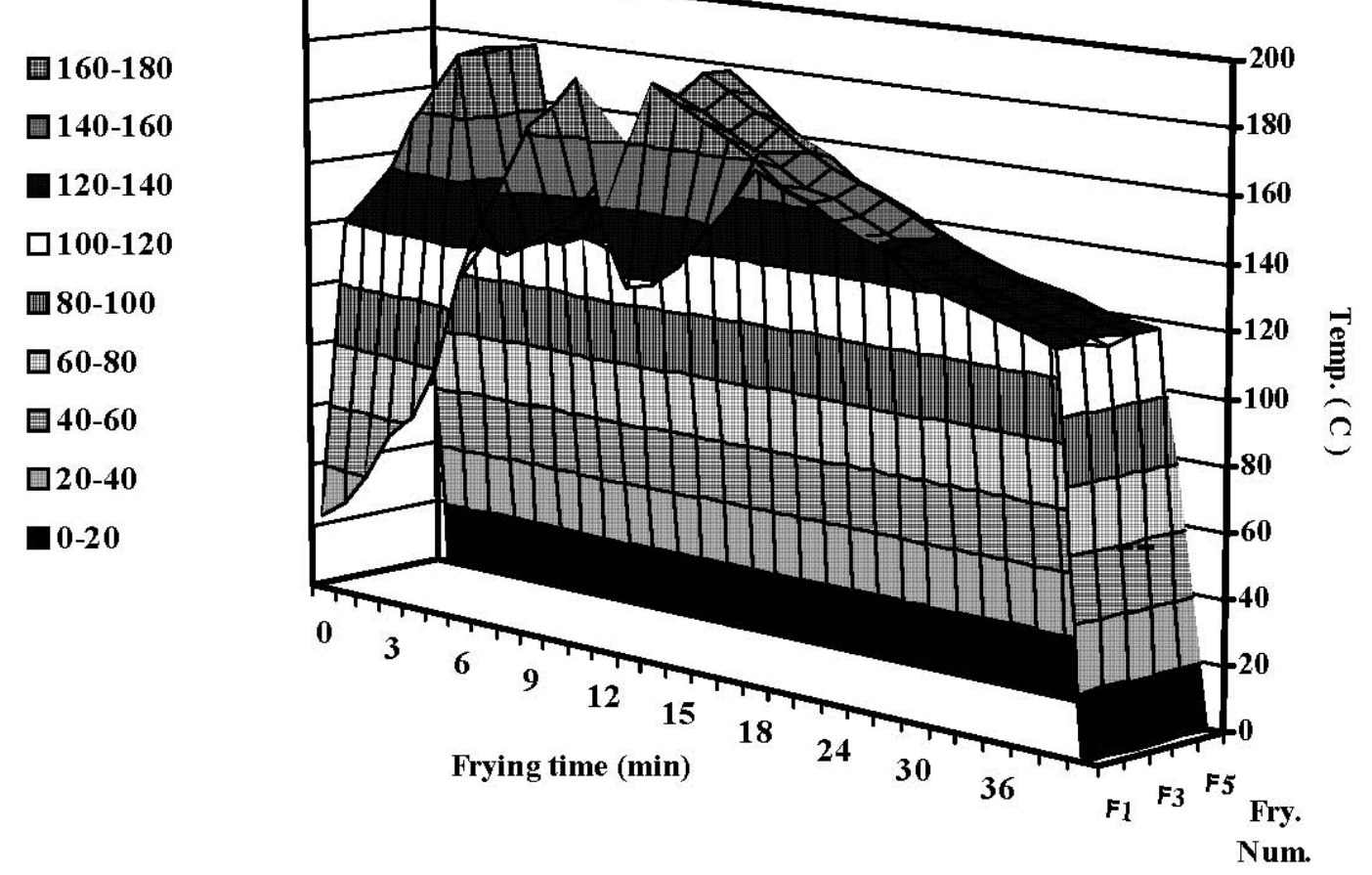

Fig. 1: Average changes in palm oil temperatures during the heating and frying operations each day (5 fryings)

trained, experienced 10 members panel after 5 , 10, 15 and 20 fryings. Panelists rated the oil odour for overall intensity on a 10 point intensity scale with $9-10=$ no odour and excellent quality and $0-1=$ strong unacceptable odour. The boarder line of odour acceptability was at 5. Colour of the frying oil was also evaluated using the same previously mentioned scale according to Larmond (1970).

Statistical analysis and mathematical models: The standard error was computed (Larmond, 1970, Murrcay, 1972, Steel \& Torrie, 1980). A correlation test was applied to study the relationship between different determined compounds and the corresponding time of frying. Simple and multiple regression analysis were carried out using Excel program (Windows, 2000).

\section{RESULTS AND DISCUSSION}

The fatty acid composition of the frying oil (Table 1) exhibited significant changes with frying time (number of frying). Total saturated fatty acids of control palm oil comprising $52.42 \%$ whereas total unsaturated ones represents $47.58 \%$. However, there was a slight increase in total saturated fatty acids combined with almost similar slight decrease in total unsaturated fatty acids as the frying time was pro- ceeded. Both linoleic and linolenic acids together decreased by $13.48 \%$ and $35.52 \%$ after 10 and 20 fryings, respectively. This indicates that the frying oil is being saturated with elongated frying times. In general, the formation of non-volatile decomposition products is largely due to thermal oxidation and polymerization of the unsaturated fatty acids present in frying medium. The rate of oxidation is roughly proportional to the degree of unsaturation of the fatty acids present (Gonzalez-Quijano \& Dobarganes, 1988, Cuesta et al., 1993). Palm oil, contains 11.39 and $0.36 \%$ linoleic and linolenic acids (Table 1) would be susceptible to relatively slight oxidation. Linoleic acid decreased significantly from 11.39 to $9.73 \%$ and then 7.33 as a result of 10 and 20 fryings, respectively, which indicates a corresponding decrease of linoleic acid in the fryer of about 14.6 and $33.6 \%$. However, no significant variations were found for stearic and oleic acid concentrations (Table 1). Alteration of used frying fats is related mainly to the unsaturated fatty acids content of the fat as well as to the heat treatment itself, and the number of frying (Cuesta et al., 1993). A very strong degree of correlation $\left(R^{2}\right)$ was found between $C_{18: 2} / C_{16: 0}$ ratio and the number of frying (Table 1). Similar finding was found also by Jaswir et al. (2000). 
Table 1: Fatty acid composition (\%) of palm oil as affected by deep-fat frying of potato chips

\begin{tabular}{|c|c|c|c|c|c|c|c|c|}
\hline \multirow{2}{*}{\multicolumn{3}{|c|}{ Fatty acids }} & \multirow{2}{*}{\multicolumn{2}{|c|}{ Control }} & \multicolumn{4}{|c|}{ Frying numbers } \\
\hline & & & & & & 10 & 20 & \\
\hline$\overline{C_{12: 0}}$ & & & & & 0.12 & & 0.94 & \\
\hline$C_{14: 0}$ & & & & & 0.71 & & 1.57 & \\
\hline $\mathrm{C}_{14: 1}$ & & - & & & 0.03 & & 0.01 & \\
\hline $\mathrm{C}_{16: 0}$ & & & 70 & & 49.63 & & 50.10 & \\
\hline $\mathrm{C}_{18: 0}$ & & & & & 3.96 & & 4.40 & \\
\hline $\mathrm{C}_{18: 1}$ & & & 83 & & 35.47 & & 34.89 & \\
\hline $\mathrm{C}_{18: 2}$ & & & 39 & & 9.73 & & 7.33 & \\
\hline $\mathrm{C}_{18: 3}$ & & & & & 0.28 & & 0.13 & \\
\hline $\mathrm{C}_{20: 0}$ & & & & & 0.07 & & 0.63 & \\
\hline Total saturated & & & 42 & & 54.49 & & 57.64 & \\
\hline Total unsaturated & & & 58 & & 45.51 & & 42.36 & \\
\hline Unsaturated/saturated & & & 08 & & 0.835 & & 0.7349 & \\
\hline Linoleic + linolenic & & & .75 & & 10.01 & & 7.46 & \\
\hline Linoleic/palmetic & & & & & 0.20 & & 0.15 & \\
\hline Dependant variables & & $\mathbf{R}$ & $\mathbf{R}^{2}$ & $\mathbf{F}$ & Sig. & Req & n equation & \\
\hline Total saturated FA & $\overline{\left(X_{1}\right)}$ & 0.9911 & 0.9824 & 55.67 & 0.08 & $\mathrm{Y}=$ & $5.8473 X_{1}$ & $(-7.46)^{*}$ \\
\hline Total unsaturated FA & $\left(\mathrm{X}_{2}\right)$ & 0.9929 & 0.9859 & 70.80 & 0.07 & $\mathrm{Y}=1$ & $9-3.7775 X_{2}$ & $(-8.37)^{*}$ \\
\hline Unsaturated/saturated & $\left(\mathrm{X}_{3}\right)$ & 0.9955 & 0.9919 & 122.299 & 0.05 & $\mathrm{Y}=1$ & $39-114.604 X_{3}$ & $(-11.06)^{*}$ \\
\hline Linoleic/palmetic & $\left(\mathrm{X}_{4}\right)$ & 0.9979 & 0.9959 & 243 & 0.04 & $\mathrm{Y}=5$ & $-221.311 X_{4}$ & $(-15.59) *$ \\
\hline
\end{tabular}

* values under the equations indicate the calculated " $\mathrm{t}_{\mathrm{s}}$ ".

Table (2) shows the average of acid values expressed as \% oleic acid of control and used palm oils up to 20 fryings. From this table, it could be noticed that the acid value of control oil was $0.202 \mathrm{mg} \mathrm{KOH} / \mathrm{gm}$ oil. The acid value of the palm oil showed a proportional relationship with the number of fryings except only at the fifth frying, where the acid value showed a downward trend. This could be explained on the basis that, up to the fifth frying the rate of FFAs volatilization was higher than that the rate of their formation. After 20 fryings, the acid value of the frying oil amounted to $0.382 \mathrm{mg}$ $\mathrm{KOH} / \mathrm{gm}$ oil. The degree of correlation $\left(\mathrm{R}^{2}\right)$ between the acid value and the frying times was high $\left(\mathrm{R}^{2}=0.7566\right)$. A suitable regression equation which describes the relationship between the acid value of the frying oil and the number of fryings could be driven (Table 2). This mathematical model reflects a high and significant correlation between the dependent and independent variables. During deep-fat frying, the oil is exposed continuously or repeatedly to elevated temperature in the presence of air and moisture. The presence of moisture in the food being fried causes hydrolysis, which results in the formation of FFAs, mono and diglycerides and glycerin. A number of chemical reactions including oxidation and thermal decomposition also occur during frying operations. Free fatty acids are formed during oxidation as a result of cleavage and oxidation of double bonds (Cuesta et al., 1993).

Polar compounds determination stands out as the most commonly used methodology to evaluate frying fat alteration and has been

Table 2: Acid value of palm oil as affected by deep-fat frying of potato chips

\begin{tabular}{|c|c|c|c|c|c|}
\hline $\begin{array}{c}\text { Number of } \\
\text { Fryings }\end{array}$ & $\begin{array}{c}\text { Frying Time (hr) } \\
\text { (Y) }\end{array}$ & $\begin{array}{c}\text { Acid Value (mgKOH/g oil) } \\
(\mathbf{X})^{*}\end{array}$ & $\mathbf{( F )}$ & $\mathbf{( r )}$ & $\left.\mathbf{( R}^{2}\right)$ \\
\hline 0 & 0.0 & $0.202 \pm 0.004$ & 9.32 & 0.8698 & 0.7566 \\
5 & 3.5 & $0.132 \pm 0.003$ & & & \\
10 & 7.0 & $0.221 \pm 0.014$ & & & \\
15 & 10.5 & $0.348 \pm 0.006$ & & & \\
20 & 14.0 & $0.382 \pm 0.010$ & & \\
\hline \multicolumn{5}{|c|}{$Y=-4.8150+45.9728 \times(3.05)^{* *}$} \\
\hline
\end{tabular}

*Acid value $\pm \mathrm{SE}$

**Value of calculated “ $\mathrm{t}$ “ 
included in the regulations to establish the maximum permissible limits of alteration in oils used for human consumption (Lumley, 1988). The results shown in Table (3) indicate a gradual and continuous increase of total polar content in the oil from $12.00 \pm 0.21 \%$ (mean \pm SD) control oil to $12.92 \pm 0.24,14.00 \pm$ $0.18,21.78 \pm 0.38$ and $26.89 \pm 0.27 \%$ when palm oil was used in 5, 10, 15 and 20 repeated and discontinuous fryings, respectively, without oil replenishment. A standard level from 25 to 27 $\%$ polar compounds is used in several European countries to indicate severely deteriorated oil (Lumley, 1988).

Heating time around $14 \mathrm{hr}$ (Table 3) or number of 20 fryings gave alteration level $(26.89 \pm 0.27 \%)$ almost around the limit recommended by regulations for discarding frying fats (25-27\% polar compounds).

It is well known that unsaturated fats are more susceptible than saturated ones to oxygen attack during thermal oxidation, and this can result in high levels of polar compounds. Therefore, the level of polar compounds in the frying palm oil should be related to the degree of unsatutation of the oil which is known to be relatively low (Cuesta et al., 1993). However, previous reports in the literature reported that unsaturation of the oil is probably one of many compositional factors affecting the formation of total polar compounds (Lumley, 1988). Also an increase in the polar fraction with the number of fryings was found when samples from used olive oil in 15 deep-fat fryings of potato chips were analyzed (Cuesta et al., 1993). On the other hand, rate of degradation is proportional to the temperature and frying time (Fedelli, 1988). Results in Table (3) also revealed that the relation between the total polar content and the number of fryings had a high $(r=0.94)$ and significant $(\mathrm{P}<0.01)$ correlation with the number of fryings. From AVs (Table 1) and polar compounds contents (Table 3), it could be concluded that during deep-fat frying of potato chips in palm oil, thermoxidative alterations took place instead of the hydrolytic process as evidenced by the higher correlation for the thermoxidative alteration (polar compounds \% vs number of fryings). Palm oil is characterized by its relative stability against thermoxidative alteration due to its relatively high degree of saturation , especially when compared with other types of oils used in food frying (Duplessis \& Meredith, 1999). Therefore, it is recommended not to use palm oil for more than 20 fryings when the heating and frying protocol used in the present investigation is employed. The regression equation presented in Table (3) could be exploited to predict either the equivalent heating time to what we have, in present investigation, suggested or the estimation of polar compounds (PC) percent (independent variable). The significance of both $t$ and $F$ values reflects the suitability of the suggested mathematical model for prediction of one dependant variable (PC\%) when the other independent variable is known or vice versa.

The UV absorption $\left(\mathrm{A}_{232}, \mathrm{~A}_{268}\right)$, peroxide value (PV) and thiobrbituric acid values (TBA) of the used palm oil in $0,5,10,15$ and 20 deep-fat fryings of potato chips are presented in Tables (4, 5 and 6). With respect to UV absorption, it is possible to divide the whole frying period (14 hr/4 days) into three phases. The first $3.5 \mathrm{hr}$ on the first day of frying resulted in a rapid decrease in $\mathrm{A}_{232}$ and a slight decrease in $\mathrm{A}_{268}$ (Table 4). The second phase, which lasted from about $7 \mathrm{hr}$ to $10.5 \mathrm{hr}$ was characterized by a considerable and significant increase in both $\mathrm{A}_{232}$ and $\mathrm{A}_{268}$ values. The third phase (from 10.5 to $14 \mathrm{hr}$ ) was characterized by a continuous increase in $\mathrm{A}_{232}$ whereas $A_{268}$ showed almost stability. On the other hand, PV showed a rapid increase till

Table 3: Polar compounds of palm oil as affected by deep-fat frying of potato chips

\begin{tabular}{|c|c|c|c|c|c|}
\hline $\begin{array}{l}\text { Number of } \\
\text { Fryings }\end{array}$ & $\begin{array}{c}\text { Frying Time (hr) } \\
\text { (Y) }\end{array}$ & $\begin{array}{c}\text { Polar compounds (\%) } \\
(\mathrm{X})^{*}\end{array}$ & (F) & ( $r)$ & $\left(\mathbf{R}^{2}\right)$ \\
\hline $\begin{array}{l}0 \\
5 \\
10 \\
15 \\
20\end{array}$ & $\begin{array}{r}0.0 \\
3.5 \\
7.0 \\
10.5 \\
14.0\end{array}$ & $\begin{array}{l}12.00 \pm 21.00 \\
12.92 \pm 00.24 \\
14.00 \pm 00.18 \\
21.78 \pm 00.38 \\
26.89 \pm 00.27\end{array}$ & 21.68 & 0.9373 & 0.8785 \\
\hline \multicolumn{6}{|c|}{$\mathrm{Y}=-6.9389+0.7957 \mathrm{X}(6.44)^{* *}$} \\
\hline
\end{tabular}

* Polar compounds (\%) \pm SE

** Value of calculated “ $\mathrm{t}$ “ 
Table 4: Effect of number and time of deep-fat frying process on absorptivity (232, $268 \mathrm{~nm})$ of palm oil used in processing of potato chips.

\begin{tabular}{|c|c|c|c|c|c|c|c|c|c|}
\hline $\begin{array}{l}\text { Number of } \\
\text { Fryings }\end{array}$ & $\begin{array}{c}\text { Frying } \\
\text { Time (hr) } \\
\text { (Y) }\end{array}$ & $\begin{array}{c}\mathbf{A}_{232} \\
\left(\mathrm{X}_{1}\right)^{*}\end{array}$ & (F) & ( $r)$ & $\left(\mathbf{R}^{2}\right)$ & $\begin{array}{l}A_{268} \\
\left(X_{2}\right)^{*}\end{array}$ & (F) & ( $r)$ & $\left(\mathbf{R}^{2}\right)$ \\
\hline 0 & 0.0 & $0.53 \pm 0.04$ & \multirow[t]{5}{*}{$6.23 * * *$} & \multirow[t]{5}{*}{0.8215} & \multirow[t]{5}{*}{0.6749} & $0.16 \pm 0.01$ & \multirow[t]{5}{*}{$0.75^{* * * * *}$} & \multirow[t]{5}{*}{0.4472} & \multirow[t]{5}{*}{0.2000} \\
\hline 5 & 3.5 & $0.29 \pm 0.02$ & & & & $0.12 \pm 0.01$ & & & \\
\hline 10 & 7.0 & $0.53 \pm 0.05$ & & & & $0.12 \pm 0.01$ & & & \\
\hline 15 & 10.5 & $0.75 \pm 0.04$ & & & & $0.18 \pm 0.02$ & & & \\
\hline 20 & 14.0 & $0.95 \pm 0.06$ & & & & $0.17 \pm 0.01$ & & & \\
\hline \multicolumn{10}{|c|}{$\begin{array}{l}Y=-4.0843+18.1709 X_{1}(2.50)^{* *} \\
Y=-6.1250+87.5000 X_{2}(0.87)^{* *}\end{array}$} \\
\hline
\end{tabular}

* Xs value $\pm \mathrm{SE}$

** Value of calculated “ $\mathrm{t}$ "

*** Significant

**** Non significant

Table 5: Effect of number and time of deep-fat frying process on peroxide value (ml equiv./ Kg) of palm oil used in processing of potato chips

\begin{tabular}{|c|c|c|c|c|c|}
\hline $\begin{array}{c}\text { Number of } \\
\text { Fryings }\end{array}$ & $\begin{array}{c}\text { Frying Time (hr) } \\
(\mathbf{Y})\end{array}$ & $\begin{array}{c}\text { Peroxide value } \\
(\mathbf{X}) *\end{array}$ & $\mathbf{( F )}$ & $\mathbf{( r )}$ & $\left.\mathbf{( R}^{2}\right)$ \\
\hline 0 & 0.0 & $01.82 \pm 0.10$ & 0.63 & 0.4164 & 0.1734 \\
5 & 3.5 & $16.84 \pm 0.20$ & & & \\
10 & 7.0 & $19.07 \pm 1.03$ & & & \\
15 & 10.5 & $18.70 \pm 0.64$ & & & \\
20 & 14.0 & $10.53 \pm 0.10$ & & \\
\hline \multicolumn{5}{|c|}{$Y=-2.7851+0.3147 \times(0.79)^{* *}$} \\
\hline
\end{tabular}

* Peroxide value \pm SE

** Value of calculated " $\mathrm{t}$ "

Table 6: Effect of number and time of deep-fat frying process on thiobarbituric acid of palm oil used in processing of potato chips

\begin{tabular}{|c|c|c|c|c|c|}
\hline $\begin{array}{c}\text { Number of } \\
\text { Fryings }\end{array}$ & $\begin{array}{c}\text { Frying Time (hr) } \\
(\mathbf{Y})\end{array}$ & $\begin{array}{c}\text { TBA } \\
(\mathbf{X})^{*}\end{array}$ & $\mathbf{( F )}$ & $\mathbf{( ~ r )}$ & $\left.\mathbf{( R}^{2}\right)$ \\
\hline 0 & 0.0 & $0.082 \pm 0.002$ & 25.83 & 0.9465 & 0.8959 \\
5 & 3.5 & $0.310 \pm 0.003$ & & & \\
10 & 7.0 & $0.328 \pm 0.006$ & & & \\
15 & 10.5 & $0.410 \pm 0.004$ & & & \\
20 & 14.0 & $0.491 \pm 0.005$ & & \\
\hline \multicolumn{6}{|c|}{$Y=-4.0743+34.1588 \times(5.08)^{* *}$} \\
\hline
\end{tabular}

* TBA value $\pm \mathrm{SE}$

** Value of calculated “ $\mathrm{t}$ “

the $7^{\text {th }}$ hr of frying followed by a noticeable decrease during the last $7 \mathrm{hr}$ of frying $\left(15^{\text {th }}\right.$ and $20^{\text {th }}$ fryings; Table 5). A steady and continuous increment in the TBA values (Table 6 ) in relation to the heating time or number of fryings have taken place. The rate of TBA increased after $3.5 \mathrm{hr}$ till the end of frying period (14 hr) was slower when compared to that shown by $\mathrm{A}_{232}$ (Table 4).

The correlation coefficients between heating times and $\mathrm{A}_{232}, \mathrm{~A}_{268}, \mathrm{PV}$ and TBA were $0.82,0.45,0.42$ and 0.95 , respectively, which indicate that TBA value of used palm oil showed the highest correlation with heating time followed by $A_{232}$; whereas both $A_{268}$ and PV showed almost similar low correlation. However, both PV and $\mathrm{A}_{268}$ measures are deceptive in heat-oxidized oils and cannot be relied upon in deep-fat frying of palm oil. Although hydrolysis did not occur, it was the oxidation which took place at high temperatures which ultimately affected the quality of fats used for deep-fat frying (Roth \& Rock, 1972).

During deep-fat frying of potato chips, a progressive loss of unsaturation of palm oil was observed (Table 1). This decrease in un- 
saturation can be attributed to the oxidation of polyunsaturated fatty acids (PUFAs), therefore, a shift in one of the double bonds occurs, producing a conjugated dienes that can be measured by UV absorption at 232nm, followed by destruction of the double bonds producing oxidation products which can be measured by PV and TBA. Measurement of unsaturation is somewhat more reliable in assessing deterioration of frying oils (Table 1) than other analytical methods, mentioned herein, but fatty acid composition of control oil before frying should be known. As previously shown in the present paper and other papers (In press), there are many methods available for analyzing heat abuse of oil. The method chosen will depend on the purpose for measuring the frying fat, the accuracy of measures described and the time allowed.

Several trials have been carried out to provide a rapid method for testing frying oils abuse. The suggested methods are based on measuring the changes, which have been taken place in oil colour during frying process. The best concentration of the oil in chloroform was found to be $20 \%(\mathrm{w} / \mathrm{v})$. Light absorption at $400 \mathrm{~nm}$ as an indication of the natural yellow colour of the oil and $\mathrm{A}_{450}$ which measures the brown pigments formed in used oil during frying are chosen. As shown in Tables (7 and 8), frying times were highly correlated with the steady, and proportional increment in $\mathrm{A}_{400}$ and $\mathrm{A}_{450}$. The correlation coefficients were as high as 0.9973 and 0.9921 for $A_{400}$ and $A_{450}$, with the frying times, respectively. This means that $99.5 \%$ and $98.4 \%\left(\mathrm{R}^{2}\right)$ of changes in absorbance (oil colour) at 400 and $450 \mathrm{~nm}$ (Tables 7 and 8) can be attributed to the heating time or the number of fryings.

The organoleptic evaluation of the control palm oil indicated that both odour and colour were considered excellent quality (mean scores $=9.45,9.33$, Table 9). Sensory analysis of the palm oil used in potatoes frying exhibited that quality deterioration have taken place with the advancement of heating times (number of fryings). It seems that there is an inverse relationship between quality evaluation of both odour and colour of the used palm oil and the time of repeated and discontinuous frying of potatoes. The linear regression equations for predicting odour and colour scores are presented in Table (9). The heating time $(Y)$ of the used palm oil could be predicted more accurately $\left(R^{2}=0.97\right)$ when both dependant variables, odour $\left(\mathrm{X}_{1}\right)$ and colour $\left(\mathrm{X}_{2}\right)$, are introduced together in a multiple regression equation (Table 9). Even after 20

Table 7: Effect of frying conditions on the adsorptivity ( $400 \mathrm{~nm}$ ) of palm oil used in deep-fat frying of potato chips

\begin{tabular}{|c|c|c|c|c|c|}
\hline $\begin{array}{c}\text { Number of } \\
\text { Fryings }\end{array}$ & $\begin{array}{c}\text { Frying Time (hr) } \\
\text { (Y) }\end{array}$ & $\begin{array}{l}\mathrm{A}_{400} \\
(\mathrm{X})^{*}\end{array}$ & (F) & $(r)$ & $\left(\mathbf{R}^{2}\right)$ \\
\hline $\begin{array}{l}0 \\
5 \\
10 \\
15 \\
20\end{array}$ & $\begin{array}{l}0.0 \\
3.5 \\
7.0 \\
10.5 \\
14.0\end{array}$ & $\begin{array}{l}0.175 \pm 0.007 \\
0.245 \pm 0.021 \\
0.285 \pm 0.009 \\
0.340 \pm 0.014 \\
0.395 \pm 0.007\end{array}$ & 545.19 & 0.9973 & 0.9946 \\
\hline \multicolumn{6}{|c|}{$Y=-11.7380+65.0625 X(23.35)^{* *}$} \\
\hline
\end{tabular}

Table 8: Effect of frying conditions on adsorptivity ( $450 \mathrm{~nm}$ ) of palm oil used in deep-fat frying of potato chips

\begin{tabular}{|c|c|c|c|c|c|}
\hline $\begin{array}{c}\text { Number of } \\
\text { Fryings }\end{array}$ & $\begin{array}{c}\text { Frying Time (hr) } \\
(\mathbf{Y})\end{array}$ & $\begin{array}{c}\mathbf{A}_{450} \\
(\mathbf{X})^{*}\end{array}$ & $\mathbf{( F )}$ & $\mathbf{( r )}$ & $\left.\mathbf{R}^{2}\right)$ \\
\hline 0 & 0.0 & $0.09 \pm 0.000$ & 186.78 & 0.9921 & 0.9843 \\
5 & 3.5 & $0.120 \pm 0.021$ & & & \\
10 & 7.0 & $0.148 \pm 0.024$ & & & \\
15 & 10.5 & $0.160 \pm 0.014$ & & & \\
20 & 14.0 & $0.193 \pm 0.025$ & & \\
\hline \multicolumn{6}{|c|}{$Y=-12.9119+140.0273 \times(13.67)^{* *}$} \\
\hline
\end{tabular}

* $\mathrm{A}_{450}$ value $\pm \mathrm{SE}$

** Value of calculated “ $\mathrm{t}$ " 
Table 9: Effect of frying conditions on the organoleptic evaluation (flavour and colour) of palm oil used in deep-fat frying of potato chips .

\begin{tabular}{|c|c|c|c|c|c|c|c|c|c|}
\hline $\begin{array}{c}\text { Number } \\
\text { of } \\
\text { Fryings }\end{array}$ & $\begin{array}{c}\text { Frying } \\
\text { Time (hr) } \\
\text { (Y) }\end{array}$ & $\begin{array}{c}\text { Flavour } \\
\text { Score } \\
\left(\mathrm{X}_{1}\right)^{*} \\
\end{array}$ & (F) & (r) & $\left(\mathbf{R}^{2}\right)$ & $\begin{array}{l}\text { Colour } \\
\text { Score } \\
\left(\mathrm{X}_{2}\right)^{*} \\
\end{array}$ & (F) & $(r)$ & $\left(\mathbf{R}^{2}\right)$ \\
\hline 0 & 0.0 & $9.45 \pm 0.50$ & \multirow[t]{5}{*}{16.63} & \multirow[t]{5}{*}{-0.9204} & \multirow[t]{5}{*}{0.8472} & $9.33 \pm 1.00$ & \multirow[t]{5}{*}{42.80} & \multirow[t]{5}{*}{$\begin{array}{l}-0.9667 \\
\end{array}$} & \multirow[t]{5}{*}{$0 . .9345$} \\
\hline 5 & 3.5 & $7.28 \pm 1.75$ & & & & $7.66 \pm 1.41$ & & & \\
\hline 10 & 7.0 & $6.55 \pm 1.51$ & & & & $6.90 \pm 1.29$ & & & \\
\hline 15 & 10.5 & $6.33 \pm 0.87$ & & & & $6.22 \pm 1.09$ & & & \\
\hline 20 & 14.0 & $5.35 \pm 1.35$ & & & & $5.77 \pm 0.83$ & & & \\
\hline \multicolumn{10}{|c|}{$\begin{array}{l}\mathrm{Y}=31.9119-3.5256 \mathrm{X}_{1}(-4.08)^{* *} \\
\mathrm{Y}=34.4194-3.8210 \mathrm{X}_{2}(-6.54)^{* *} \\
\mathrm{Y}=35.4728+4.4878 \mathrm{X}_{1}-8.3868\end{array}$} \\
\hline
\end{tabular}

* Flavour, colour scores \pm SE

** Value of calculated “ $\mathrm{t}$ “

repeated and discontinuous fryings, the used palm oil was organoleptically still considered acceptable. As could be driven from the regression equations in Table (9), frying of potatoes in palm oil for $3.5 \mathrm{hr}$ and $3.8 \mathrm{hr}$ may decrease the average scores of both odour and colour by 1 unit, respectively. Also by utilizing the same equations the times needed for rejecting the used oil odour and colour by the panelists were predicted to be 14.3 and $15.3 \mathrm{hr}$, respectively. When both flavour $\left(\mathrm{X}_{1}\right)$ and colour $\left(\mathrm{X}_{2}\right)$ variables are introduced in the multiple regression equation presented in Table (9), the predicted time for oil rejection was estimated to be 15.98 hr. The efficiency of the multiple regression equation presented in Table (9) was high enough to indicate that $97 \%$ of used oil changes, as a result of frying, could be detected by trained and experienced panelists when both flavour $\left(\mathrm{X}_{1}\right)$ and colour $\left(\mathrm{X}_{2}\right)$ mean scores are used in the same regression equation.

After evaluating the different quality parameters and investigating the effect of repeated and discontinuous deep-fat frying on the quality of palm oil, then we tried to design suitable mathematical equations for estimating decisively and accurately the independent variable ( $\mathrm{Y}=$ frying time or number of fryings - Fig. 1) when some dependant variables are known. As we mentioned before, no one single technique can easily evaluate frying oil quality, thus utilizing and analyzing the results obtained from several analytical techniques together may be more reliable. However, assessment of used frying oils could easily be used to control the usage of frying oils by advising the consumers or resturant's owners with the maximum allowable heating times or number of fryings in which the oil could be subjected before discarding.
Multiple regression equations which was formed by using step-wise regression are presented in Table (10). The mathematical models found in Table (10) are the best group chosen to express the relationship between the independent variable ( $\mathrm{Y}=$ heating time or number of fryings) and the dependant variables $\left(\mathrm{X}_{\mathrm{s}}\right)$. Multiculinary equations, whatever its strength, are not included in Table (10). The mathematical formulas are arranged descendingly according to highest strength and significance as well as lowest standard error. For example, the most suitable equation in Table (10) is equation No. 1 which describes the relationship between the independent variable $(\mathrm{Y})$ and three dependant variables, i.e. $\mathrm{A}_{400}\left(\mathrm{X}_{1}\right)$, TBA value $\left(\mathrm{X}_{3}\right)$ and $\mathrm{PC} \%$ $\left(\mathrm{X}_{4}\right)$. The degree of correlation $\left(\mathrm{R}^{2}\right)$ between the independent variable $\mathrm{Y}$ and these dependant variables (Xs) are as high as almost equal 1 , whereas both $\mathrm{F}$ and $\mathrm{t}$ values are very high (Table 10). This reflects the high validity of the mathematical model(s) and the strong relationship between $\mathrm{Y}$ and the chosen $\mathrm{X}_{\mathrm{s}}$, which entered to the equation in a step-wise manner. Equation 1 and also other equations presented in Table (10) could accurately predict, without any doubt, the frying time of the palm oil which has been exposed to repeated and discontinuous deep-fat frying of potato chips in palm oil.

\section{ACKNOWLEDGMENT}

We greatly appreciate the financial support from the Academy of Scientific Research and Technology for the research project "Rationalizing utilization of edible oils in local consumption”. 
Table 10: The best mathematical models employed for accurate evaluation of frying times of potato chips in palm oils during repeated and discontinuous frying operations.

\begin{tabular}{|c|c|c|c|c|c|c|}
\hline No & Best mathematical models & (r) & $\left(\mathbf{R}^{2}\right)$ & (F) & $\begin{array}{l}\text { True } \\
\text { (Y) } \\
\text { (hr) }\end{array}$ & $\begin{array}{c}\text { Calculated } \\
\text { (Y) } \\
\text { (hr) } \\
\end{array}$ \\
\hline 1 & $\begin{array}{r}\mathrm{Y}=-6.5753+22.2254 \mathrm{X}_{1}+17.6877 \mathrm{X}_{3}+0.1032 \mathrm{X}_{4} \\
(85.45)^{*} \quad(127.38)\end{array}$ & 1.0000 & 1.0000 & 74610.89 & 7.00 & 7.00 \\
\hline 2 & $\begin{array}{rcc}Y=-11.4809+57.3553 X_{1}+6.9522 & X_{5}+0.0131 X_{7} \\
(7.69) & (1.29) * & (0.28)^{*} \\
\end{array}$ & 0.9992 & 0.9984 & 203.39 & 10.50 & 10.68 \\
\hline 3 & $\begin{array}{c}\mathrm{Y}=-11.8277+86.3550 \mathrm{X}_{2}+0.3170 \mathrm{X}_{4}+0.0743 \mathrm{X}_{7} \\
(3.62)^{*} \\
(2.45)^{*}\end{array}$ & 0.9989 & 0.9978 & 154.00 & 14.00 & 14.14 \\
\hline 4 & $\begin{array}{rcc}\mathrm{Y}=-11.8894+4.7269 \mathrm{X}_{1}+103.6200 \mathrm{X}_{2}+0.1651 \mathrm{X}_{4} \\
(0.45)^{*} & (3.68)^{*} & (1.08)^{*} \\
\end{array}$ & 0.9975 & 0.9950 & 66.37 & 0.00 & 0.24 \\
\hline 5 & $\begin{array}{rc}\mathrm{Y}=-12.1742+110.9040 \mathrm{X}_{2}+0.1943 \mathrm{X}_{4} \\
(38.48)^{*} & (3.26)^{*} \\
\end{array}$ & 0.9970 & 0.9880 & 165.53 & 7.00 & 6.96 \\
\hline 6 & $\begin{array}{c}\mathrm{Y}=-11.5942+58.6032 \mathrm{X}_{1}+0.0946 \mathrm{X}_{4} \\
(5.29)^{*} \\
(0.66)^{*}\end{array}$ & 0.9959 & 0.9919 & 122.51 & 14.00 & 14.10 \\
\hline 7 & $\begin{array}{c}\mathrm{Y}=-10.0020+0.7933 \mathrm{X}_{4}+0.2572 \mathrm{X}_{7} \\
(9.91)^{*}\end{array}$ & 0.9911 & 0.9822 & 55.26 & 14.00 & 14.04 \\
\hline $\begin{array}{l}* \mathrm{Va} \\
\mathrm{X} 1= \\
\mathrm{X} 3= \\
\mathrm{X} 5\end{array}$ & $\begin{array}{l}\text { lues of calculated “ } \mathrm{t} \text { “. } \\
\text { A400 } \\
\text { TBA } \\
\text { Acid value }\end{array}$ & $\begin{array}{l}=\text { Time } \\
=\text { A } 450 \\
=\text { PC }(\% \\
=\text { PV. }\end{array}$ & fryin & & & \\
\hline
\end{tabular}

\section{REFERENCES}

AOAC. 1995. Official Methods of Analysis of AOAC International. $16^{\text {th }}$ ED., Vol. II. Edited by Cunniff, P., Virginia, USA.

Ashour, A.A. 1991. Effect of Dought on Some Biochemical Constituents of Plant. Ph. D. Thesis, Fac., Agric., Ain Shams Univ., Cairo.

Berger, K.G. 2005. The use of frying oil in frying frying oil series. Malaysian Palm Oil Promotion Council Jalan Perbandoxan 44301 Kelana Jaya, Selangor, Malysia.

Blumental, M.M. 1996. Frying technology, in Bailley's Industrial Oil \& Fat Products, $5^{\text {th }}$ edn., edited by Y.H. Hui: John Wiley \&Son Inc., New York, Vol. 3, pp. 429-481.

Cuesta, C., Sanchez-muniz, F.J., Garido-Polonio, C., Lopez-Varela, S.\& Arroya, R. 1993. Thermoxidative and hydrolytic changes in sunflower oil used in fryings with a fast turnover of fresh oil. J. Am. Oil Chem. Soc. 70 (11): 1069-1073.

Danopolus, A.A.\& Ninni, V.L. 1972. Detection of frozen fish deterioration by ultraviolet spectrophotometric method. J. Food Sci., 37: 649.

Du-plessis, I.M.\& Meredith, A.J. 1999. Palm olein quality parameter changes during industrial production of potato chips. J. Am. Oil Chem. Soc. 76 (6): 731-738.

Fedelli, E. 1988 .In Frying of Food, Principle, Changes, New Approaches, edited by $\mathrm{G}$. Varela, A.E. Bender \& I.D. Morton, Ellis Horwwod Ltd., Chichester, pp. $52-81$.

Gonzalez-Quijano, G.R. \& Dobarganes, M.C. 1988. In Frying of Food, Principles, changes, New Approaches, edited by G.Varela, A.E. Bender \& I.D. Morton, Ellisd Horwood Ltd., Chichester, pp.141-154.
Hassan, I.M. 1980. The Effect of Irradiation Treatments Alone or Accompanied with Other Treatments on Some Properties of Meat. Ph. D. Thesis, Fac. of Agric., Ain Shams Univ., Cairo Egypt.

Jaswir, I., Cheman, B.Y. \& Kitts, D.D. 2000. Optimization of physicochemical changes of palm olein antioxidants during deep-fat frying. JAOCS, 77 (11):1161-1168.

Keeney, P.G. 1971. A guide to controlling oxidation in butter creams. Candy and Snack Inc., 136: 58

Larmond, E. 1970. Methods for Sensory Evaluation of Food. Publication No. 1284 , Canada Dept. of Agric., Ottawa.

Lumley, I.D. 1988. Polar Compounds in Heated Oils, in Frying of Food: Principles, Changes New Approach, edited by G. Vareia, A.E. Bender \& I.D. Morton, ellishor. Wood Ltd., Chichester, England, pp: 166-173.

Metcalfe, L.C., Schmitz, A.A. \& Pleca, J. R. 1966. Rapid preparation of fatty acid esters from lipids for gas chromatographic analysis. Anal. Chem. 38: 514-515.

Murrcay, R.S. 1972. Statistics. Mc. Graw-Hill International Book Company, New York.

Roth, H. \& Rock, S.B. 1972. The chemistry and technology of frying fat. 1. Chemistry. The bakers Digest. 46: 38.

Steel, R.C. \& Torrie, J.H. 1980. Principle and Procedures of Statistics. Mc. Graw-Hill, International Book Company, New York.

Stevenson, S.G., Vaisey-Genser, M. \& Eskin, N.A.M. 1984. Quality control in the use of deep frying oils. J. Am. Oil Chem. Soc. 61: 1102-1108. 


\section{القلي العميق للبطاطس في زيت النخيل وعلاقته بتقييم صفات الجودة \\ إبرلهيم محمد مسن ، علالف أنور لبوعرب

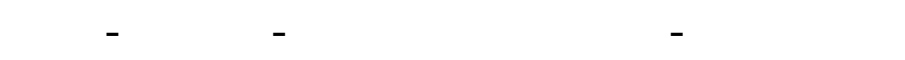

لجريت هذه الدرلسة بهوف تتسع خواص الجودة المسية والكيماوية لزيت النخل عند لستخدامه في عمليك القلي

المتكرر والمتطع لشرائح الطلس على درجلت حرارة متزلية. وقد أوضحت النتائج ما يلي:

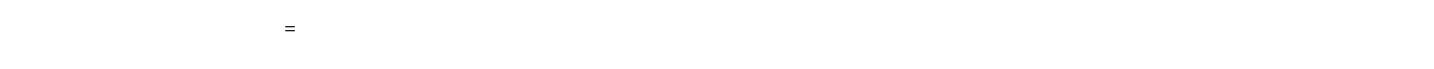

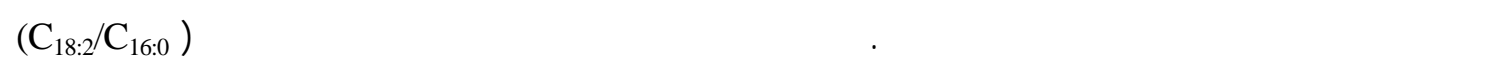
وزمن القلي، كما حثت زياة في نسبة أرقلم الحموضة نتيجة لزيادة تكرارلمستخدلم الزيت في عملية القلي.

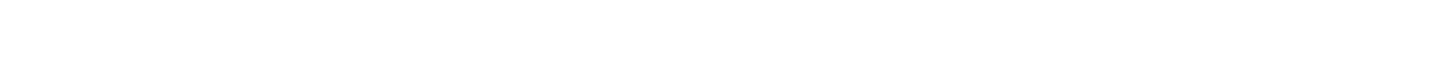

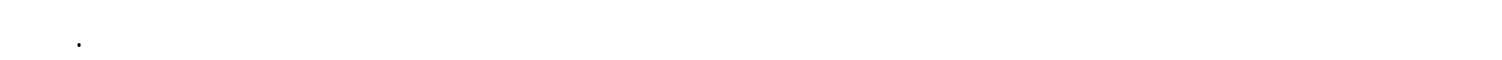

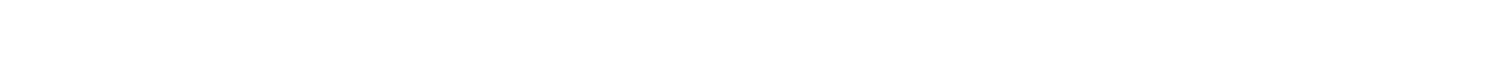

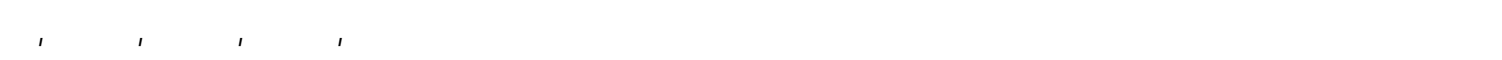

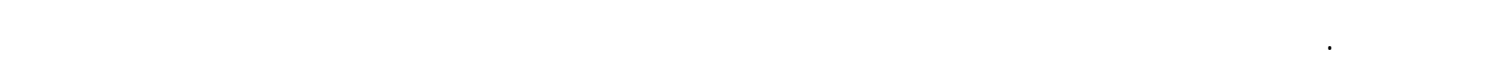

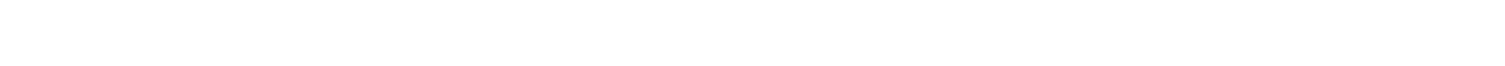
نانوميتر.

ومن نلحية لخرى أوضصت نتائج القيم الهسي حدوث تدهور ملحوظ في درجة جودة زيت النخل المستخهم في القلي

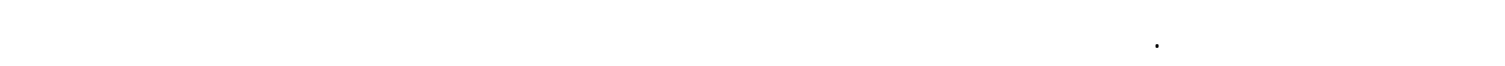

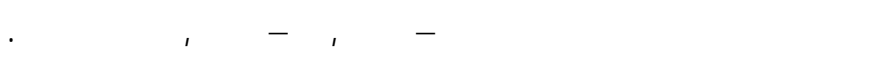

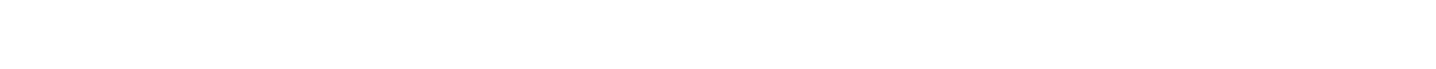
مدى صلاحية زيت النخل في عملية القلي. 